Revista Brasil. Bot., V.26, n.1, p.23-34, mar. 2003

\title{
Morphology and anatomy of the fruit and seed in development of Chorisia speciosa A. St.-Hil. - Bombacaceae
}

\author{
JULIANA MARZINEK ${ }^{1}$ and KÁTHIA S.M. MOURÃO ${ }^{1,2}$
}

(received: October 11, 2001; accepted: August 28, 2002)

\begin{abstract}
Morphology and anatomy of the fruit and seed in development of Chorisia speciosa A. St.-Hil. - Bombacaceae). The structure of the fruit and seed in development of Chorisia speciosa are described with the main purpose of clarifying the origin and nature of the hairs that cover the seeds and aiding future taxonomical and ecological studies of the group. The fruit is an ellipsoid loculicide capsule and presents the exocarp formed by 7-10 cells layers, with very thick walls and evident simple pits. A great number of mucilage secretory cavities and ramified vascular bundles, accompanied by fibers, occur in the parenchymatic mesocarp. The endocarp derives from the ventral epidermis of the ovary wall, whose cells undergo a gradual elongation, become lignified, and constitute the trichomes which cover the mature seeds. The fruit aperture occurs by means of a suture evident in the ovarian wall in the middle region of the carpel leaf. Anatropous and bitegmic ovules, provided by a hypostase, give rise to campilotropous and bitegmic seeds. The testa is uniseriate, the exotegmen is completely formed by macrosclereids, and mucilage secretory cavities occur in the mesotegmen. The endotegmen, which is differentiated in the endothelium, is crushed in the mature seed. The plicate embryo, which occupies practically the entire seminal cavity, is found between endosperm layers, both being rich in lipids.
\end{abstract}

Key words - Chorisia speciosa, fruit, seed

RESUMO -(Morfologia e anatomia do fruto e da semente em desenvolvimento de Chorisia speciosa A. St.-Hil. - Bombacaceae). Descreveu-se a estrutura do fruto e da semente em desenvolvimento de Chorisia speciosa, visando elucidar a natureza dos pêlos que envolvem as sementes e subsidiar futuros estudos taxonômicos e ecológicos do grupo. O fruto é uma cápsula loculicida, elipsóide e apresenta o exocarpo constituído por 7-10 camadas de células com paredes celulares muito espessas com pontoações simples e evidentes. O mesocarpo parenquimático contém numerosas cavidades secretoras de mucilagem e feixes vasculares ramificados, acompanhados por fibras esclerenquimáticas. O endocarpo deriva da epiderme ventral da parede ovariana, cujas células alongam-se gradualmente, tornam-se lignificadas, cosntituindo os tricomas que envolvem as sementes. A deiscência do fruto ocorre por meio de uma sutura, na região mediana da folha carpelar, já evidente na parede ovariana. Os óvulos anátropos, bitegumentados e providos de hipóstase, originam sementes campilótropas e bitegumentadas. A testa é unisseriada. O exotégmen é constituído inteiramente por macroesclereídes; no mesotégmen ocorrem cavidades secretoras de mucilagem; e o endotégmen, que se diferencia no endotélio, torna-se colapsado na semente madura. $\mathrm{O}$ embrião plicado, que ocupa praticamente toda a cavidade seminal, encontra-se entre camadas de endosperma, sendo ambos ricos em material lipídico.

Palavras-chave - Chorisia speciosa, fruto, semente

\section{Introduction}

Chorisia speciosa A. St.-Hil., an arboreal deciduous species with wide distribution in Brazil, occurs from Paraíba State to Rio Grande do Sul State (Santos 1967, Pio Corrêa 1978). This species has great economic and ornamental potential, living preferentially in wet habitats, being frequent in river valleys and small depressions (Santos 1967). Dias et al. (1992) classifies this species as secondary in the ecological succession.

\footnotetext{
1. Universidade Estadual de Maringá, Departamento de Biologia, Avenida Colombo, 5790, 87020-900 Maringá, PR, Brasil.

2. Corresponding author: ksmmourao@uem.br
}

Anatomical studies about species of Bombacaceae are scarce. With respect to the anatomy of the reproductive organs, Corner (1976) describes the seeds of only five species without referring to Chorisia speciosa. More recently, Donato (1991) carried out an anatomical study of the flower of this species and Galati \& Rosenfeldt (1997) described in detail the ovule ontogeny, with special reference to the embryonic sac development of Ceiba insignis (Kunth) Gibbs \& Semir (= Chorisia speciosa A. St.-Hil.).

Lack of detailed ontogenetical studies of fruits and seeds of angiosperms has generated difficulty in fruit classification and in the correct description of the structures that cover the seeds. Hairs which cover the seeds in Chorisia speciosa have been classified by Ramalho (1972) as pilose aril. However, the term aril, 
in a broad sense, is used to describe any fleshy outgrowth which has its origin in the ovule or seed in development and covers it partially or completely. Cronquist (1981) and Barroso et al. (1999), in turn, described that in Bombacaceae seeds are usually covered by a pilose tissue derived from the inner wall of the ovary. However, these authors did not conduct ontogenetical studies of the fruits in this family.

In the present study, the fruit and seed ontogeny of Chorisia speciosa A. St.-Hil. is described in detail, with the main purpose of confirming the origin of the hairs that cover the seeds and amplifying the knowledge about the biology of this species.

\section{Materials and methods}

The botanical material used consisted of floral buds, flowers and fruits of Chorisia speciosa A. St.-Hil. in different stages of development.

Studied material - BRASIL: PARANÁ: Maringá, 10-VI-1999, J. Marzinek \& N. T. Kokubo 2 (HUM 5169); 21-III-2000, A.M.J. Corsi \& K.S.M. Mourão 39 (HUM 6017); 21-III-2000, A.M.J. Corsi, N.T. Kokubo \& K.S.M. Mourão 38 (HUM 6018); 1-XI-2000, K.S.M. Mourão 41 (HUM 7599); 1-XI-2000, K.S.M. Mourão 40 (HUM 7600).

The morphologic characters of the fruits and seeds were described and illustrated from 50 units of fresh material, collected from five individuals. A pachymeter was used for fruit and seed measures (length and diameter) and the fresh weight was obtained using an electronic scale. The number of seeds per fruit was also determined. The arithmetic average and the deviation-pattern was calculated for each of the obtained variables. The nomenclature used to describe fruit and seed patterns was based on Radford et al. (1974). The fruit type description was based on Barroso et al. (1999).

Samples of material for morphological and anatomical studies were fixed in F.A.A. 50 (Johansen 1940). The material was conserved in ethanol $70 \%$ (Jensen 1962). The anatomical description was made from the analysis of semipermanent and permanent slides made with transversal and longitudinal sections of the developing pericarp and seeds. The slides, the specific tests and the illustrations were made in agreement with methodology described by Mourão \& Beltrati (1995). The preparation of permanent plant material slides embedded in glycol methacrylate according to the technique described by Gerrits (1991) was also used. These slides were stained with Toluidine Blue O (O'Brien et al. 1964) and mounted in Permount. The terminology adopted to define the pericarp layers is in agreement with Roth (1977) and the nomenclature used in the seed description was that defined by Corner (1976) and modified by Schmid (1986).

\section{Results and Discussion}

Fruit development - Chorisia speciosa has a superior, pentacarpellary and pentalocular ovary. The ovules are arranged in axile placentation. The dorsal epidermis is uniseriate and presents cubic cells covered by a thin cuticle. Anticlinal divisions are observed in this epidermis. The ovarian mesophyll is composed of fundamental parenchyma with a number of mucilage cavities and collateral vascular bundles. The latter accompanied by cells with phenolic contents (figures 1-3). The ventral epidermis resembles the dorsal epidermis, but presents cells with small dimensions (figure 8). These features are in accordance with the description of Donato (1991) for the gynoecium of the same species.

The presence of mucilage secretory structures is a common feature in most families belonging to Malvales (Cronquist 1981, Judd et al. 1999). Donato (1991) mentions that in Chorisia speciosa mucilaginous canals occur in all whorl flowers. Cross and longitudinal sections of the ovary of this species show rounded structures and are therefore classified as secretory cavities (figures 1-2).

In Chorisia speciosa, the exocarp is derived from the ovarian dorsal epidermis and from six to nine subepidermical layers of the ovarian mesophyll. These cells present very thick walls, in which evident simple pits are observed. Stomata are observed in the exocarp of the fruit in development (figure 6).

The mesocarp, derived from the ovarian mesophyll, becomes very fibrous due to the great differentiation of fibers around the vascular bundles (figure 4). Mucilage secretory cavities immersed in parenchymatic tissue are still observed in the immature fruit.

The endocarp derives from the ventral epidermis of the ovary wall, whose cells undergo a gradual elongation, become lignified, and constitute the trichomes which cover the mature seeds (figures 8-11). This fact is in agreement with the descriptions of Cronquist (1981) and Barroso et al. (1999). A ventral meristem, arises in the two subepidermical layers, can be observed in the inner part of the ovarian mesophyll (figure 10). This meristem seems to be responsible by the radial elongation of the fruit.

The fruit of Chorisia speciosa is an ellipsoid loculicide capsule which presents green coloration during the greater part of its development. It measures 14.68 $\pm 2.35 \mathrm{~cm}$ of length per $7.82 \pm 0.9 \mathrm{~cm}$ of diameter (figure 12), weighs when immature $421 \pm 148.29 \mathrm{~g}$ (weighed with fresh matter) and presents $100.59 \pm 53.09$ seeds 

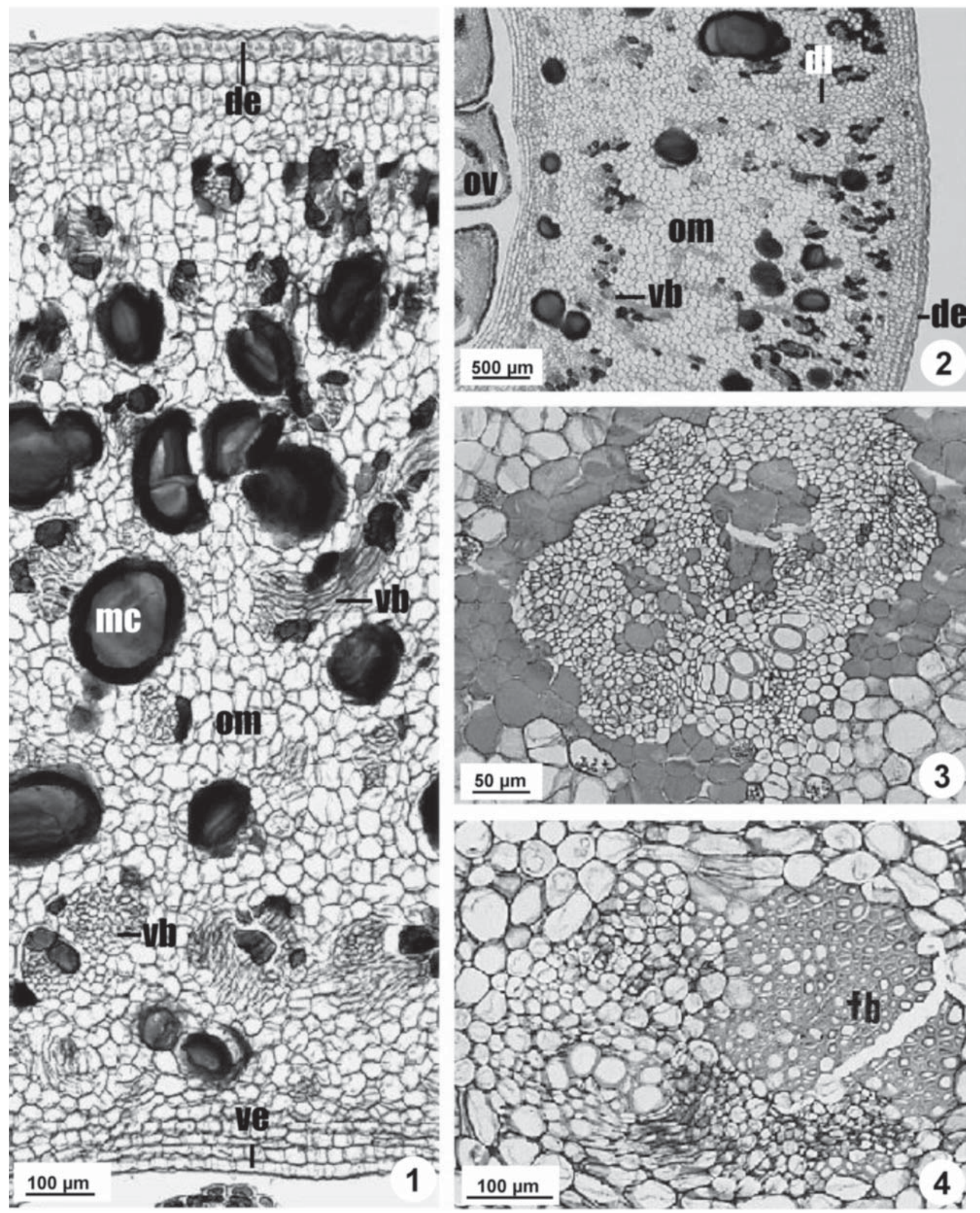

Figures 1-4. Chorisia speciosa.1-2. Ovary wall in medium longitudinal and transversal sections, respectively. 3-4. Detail of the vascular bundle in the mesocarp of the young and immature fruit, respectively. ( $\mathrm{de}=$ dorsal epidermis, $\mathrm{dl}=\mathrm{dehiscence}$ line, $\mathrm{fb}$ $=$ fibers, $\mathrm{mc}=$ mucilagenous cavity, om = ovarian mesophyll, ov $=$ ovule, $\mathrm{vb}=$ vascular bundle, $\mathrm{ve}=$ ventral epidermis $).$ 

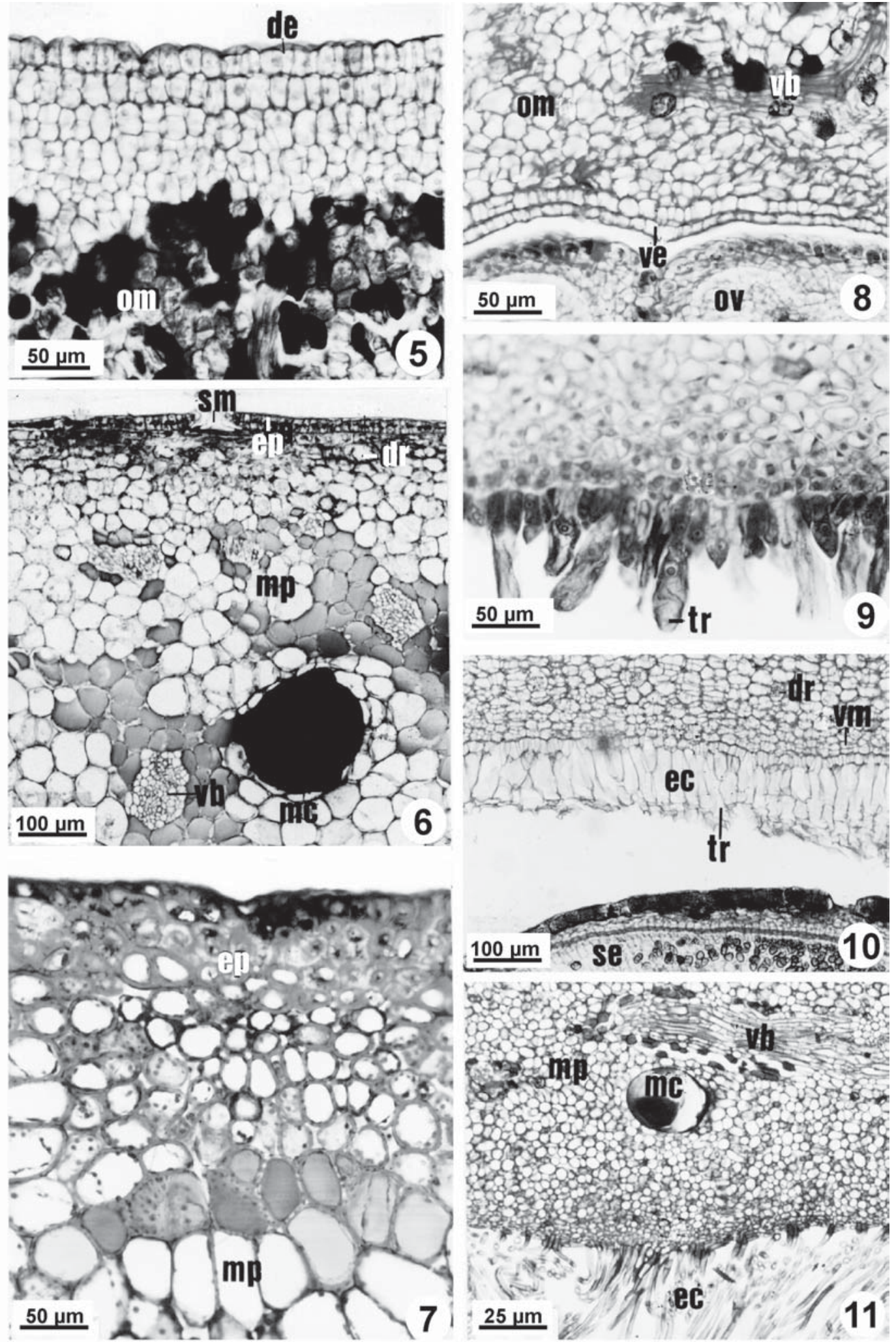

Figures 5-11. Chorisia speciosa. Details in transversal sections, respectively. 5. Outer and inner region of the ovary wall. 6-7. Exocarp of the young and immature fruit. 8, 9-11. Endocarp of the young, immature and mature fruit, evidencing the trichomes differentiation. $(\mathrm{de}=$ dorsal epidermis, $\mathrm{dr}=$ druse, $\mathrm{ec}=$ endocarp, $\mathrm{ep}=$ exocarpo, $\mathrm{mc}=$ mucilagenous cavity, $\mathrm{mp}=$ mesocarp, om $=$ ovarian mesophyll, ov $=$ ovule, $\mathrm{se}=$ seed, $\mathrm{sm}=$ stomata, $\mathrm{tr}=$ trichomes, $\mathrm{vb}=$ vascular bundle, $\mathrm{vm}=$ ventral meristem $)$. 
per fruit. Its aperture occurs by means of a suture evident in the ovarian wall in the middle region of the carpel leaf (figure 2). The fibers which accompany the vascular bundles probably take an active role in fruit dehiscence when the pericarp loses water at maturation. After dehiscence, the valves acquire brown coloration and are detached from the seeds covered by trichomes, which remain attached to the plant until dispersion (figures 13-14).

Spjut (1994) uses only the pericarp morphology in his classification, without refers to the seed types, these appendages, reserve tissue and embryo. Although Barroso et al. classification (1999) uses a larger number of characteristics comparing to the last author, for both

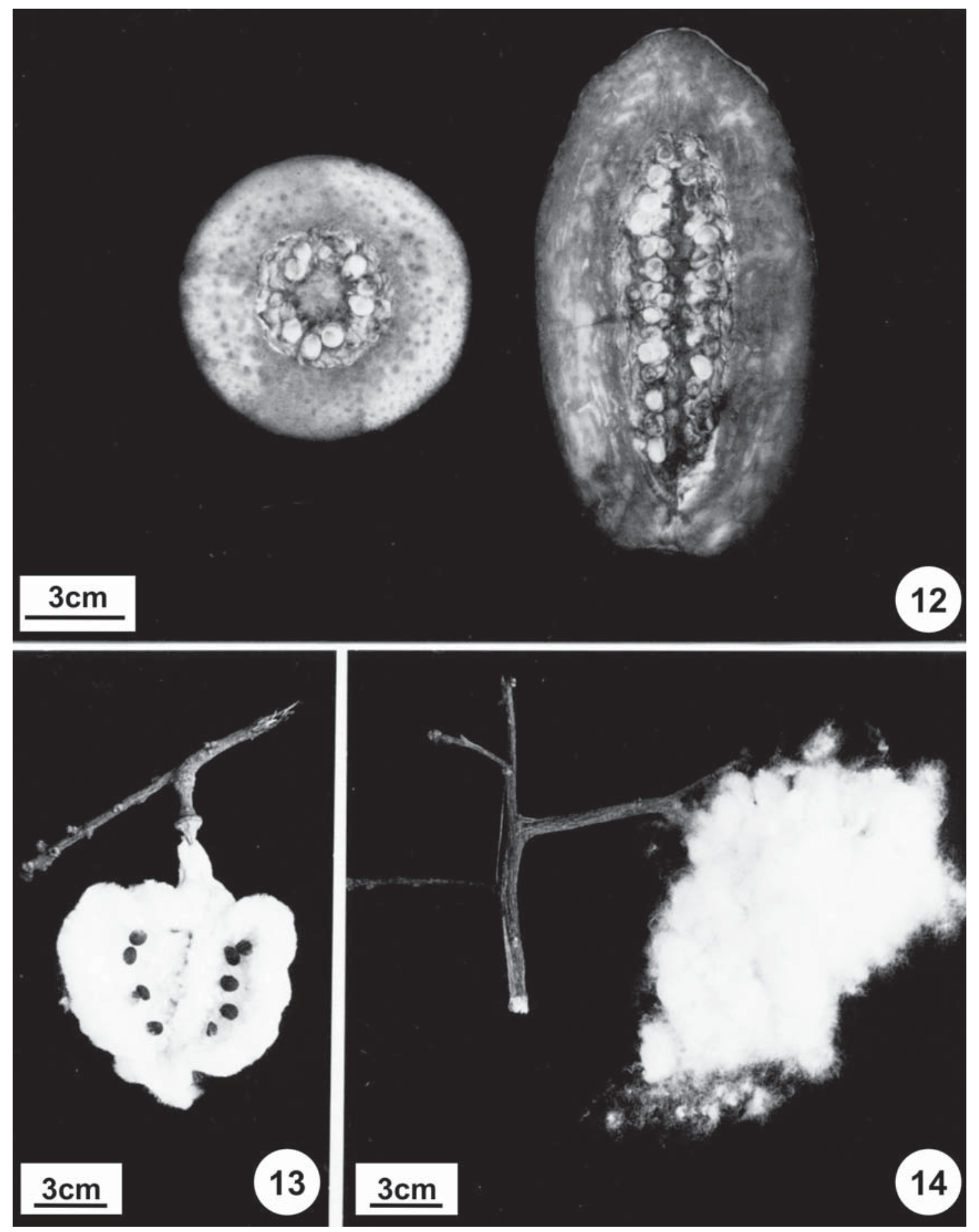

Figures 12-14. Chorisia speciosa. 12. Immature fruit in transversal (to the left) and longitudinal section (to the right). 13-14. Mature fruit after the valves have fallen. 
the fruit type of Chorisia speciosa is a loculicide capsule.

Seed development - Ovules are anatropous and bitegmic; the outer integument shows three to five cell layers and the inner three layers. The outer epidermis of the outer integument is formed by cube-shaped cells, bigger than the other cells of the ovule, in which phenolic contents are observed. The external, medium (between the two integuments) and inner cuticle (between the inner integument and the nucellus) can be observed. The
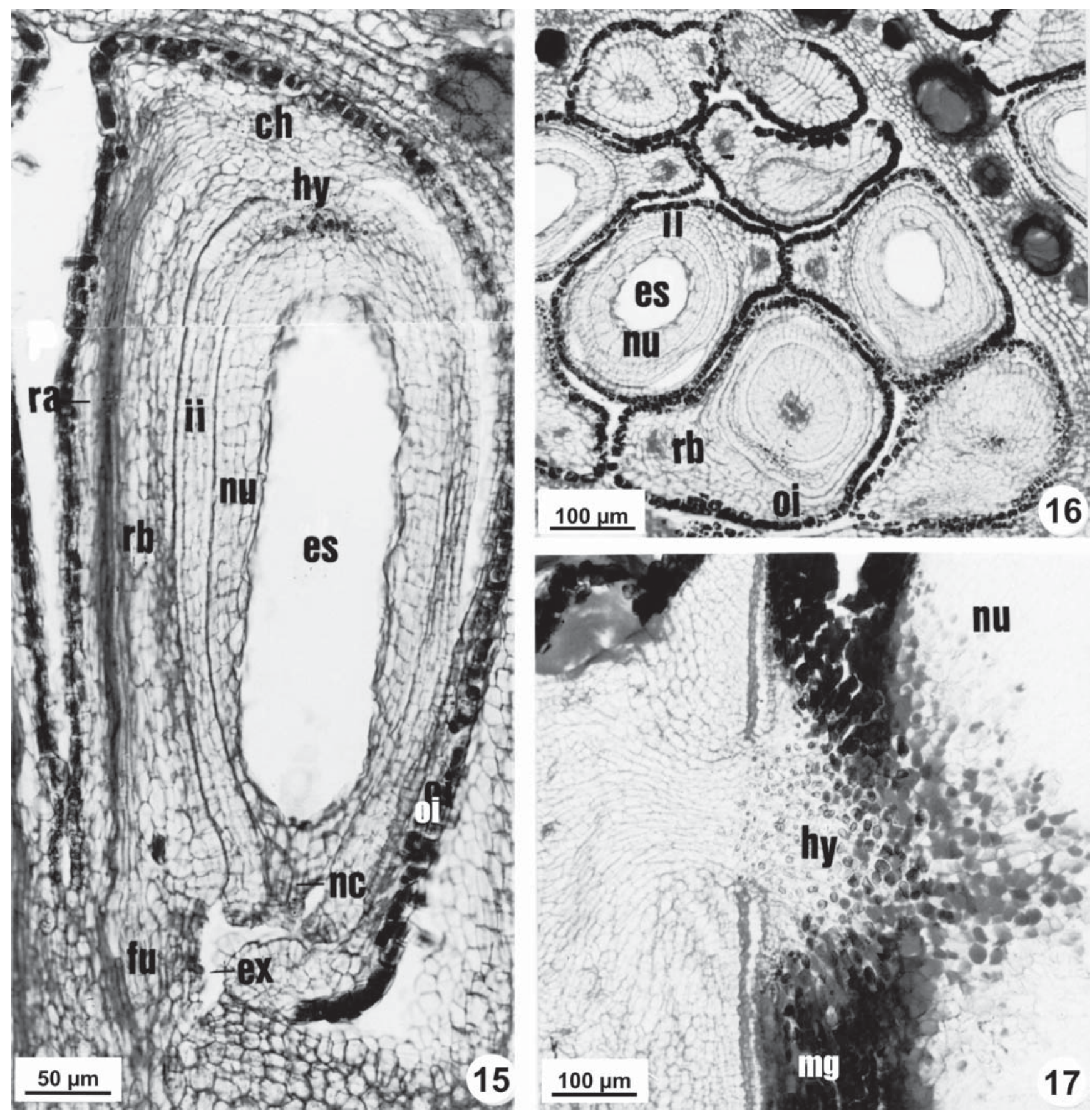

Figures 15-17. Chorisia speciosa. 15-16. Ovule in longitudinal and transversal section, respectively. 17. Detail of the hypostase in a young seed. $(\mathrm{ch}=$ chalaza, $\mathrm{es}=$ embryonic sac, $\mathrm{ex}=$ exostome, $\mathrm{fu}=$ funicle, $\mathrm{hy}=$ hypostase, $\mathrm{ii}=$ inner integument, $\mathrm{mg}=$ mesotegmen, $\mathrm{nc}=$ nucellar cap, $\mathrm{nu}=$ nucellus, $\mathrm{oi}=$ outer integument, $\mathrm{ra}=$ raphe, $\mathrm{rb}=$ rapheal bundle). 
micropyle channel is only formed by the exostome The endostome is occupied by nucellar tissue, which constitutes the nucellar cap. In the chalazal region, a group of cells with thin walls between the integuments occurs. These cells contain phenolic substances and constitute a hypostase. The provascular strand transverses the funicle and the raphe, extending only up to the chalaza (figures 15-16). These descriptions are in agreement with Donato (1991) and Galati \& Rosenfeldt (1997).
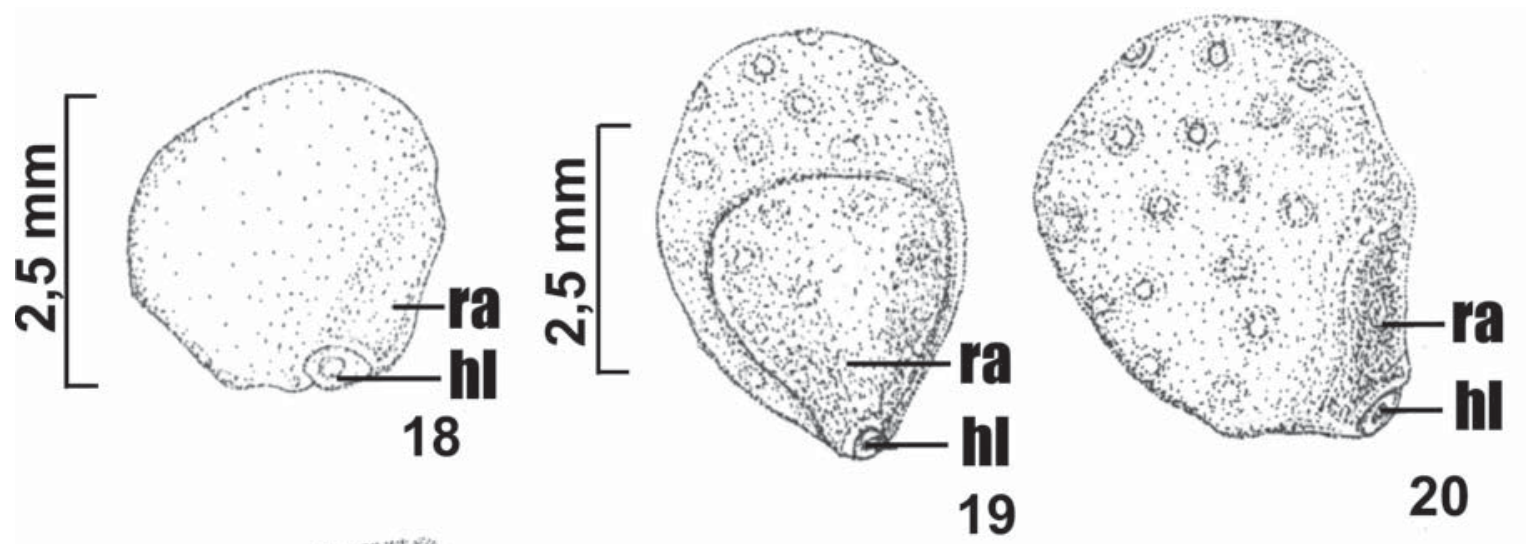

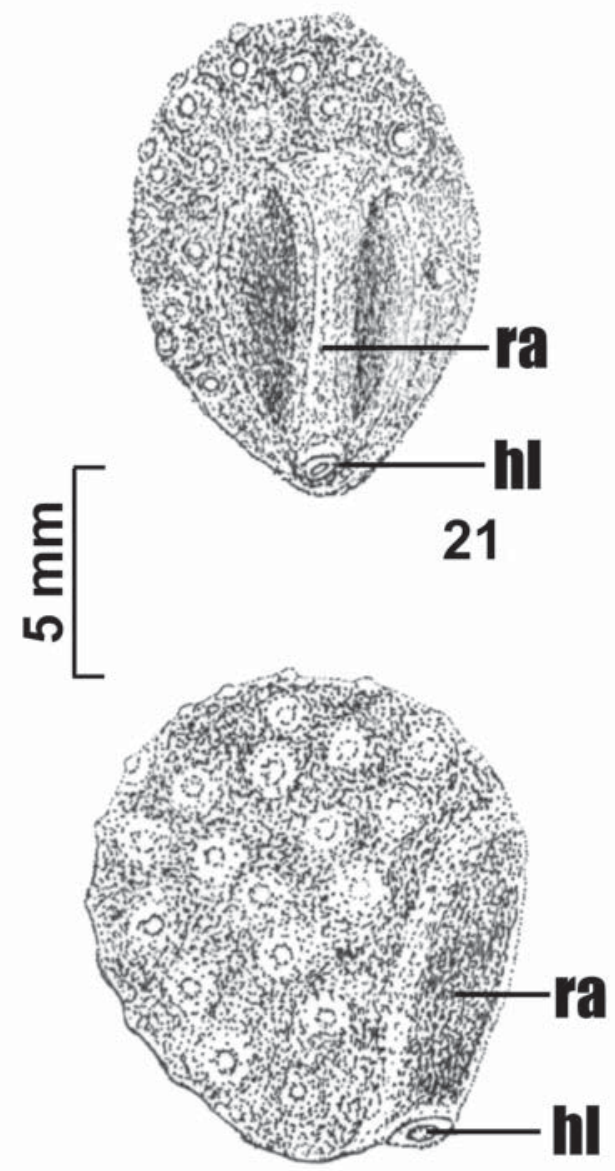

22

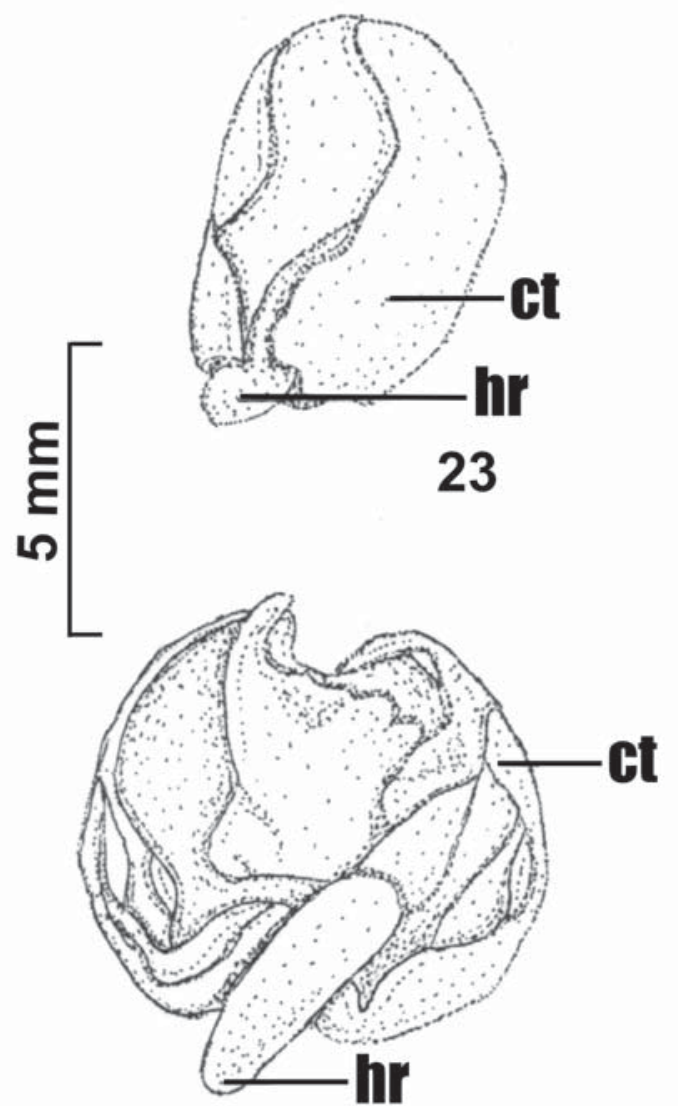

24

Figures 18-24. Chorisia speciosa. 18. Very young seed in lateral view. 19-20. Young seed in lateral and rapheal view, respectively. 21-22. Mature seed in lateral and rapheal view, respectively. 23-24. Embryo evidencing folded and manually separate cotyledons, respectively $(\mathrm{ct}=$ cotyledons, $\mathrm{hl}=$ hillum, $\mathrm{hr}=$ hipocotyl-radicle axis, $\mathrm{ra}=$ raphe $)$. 

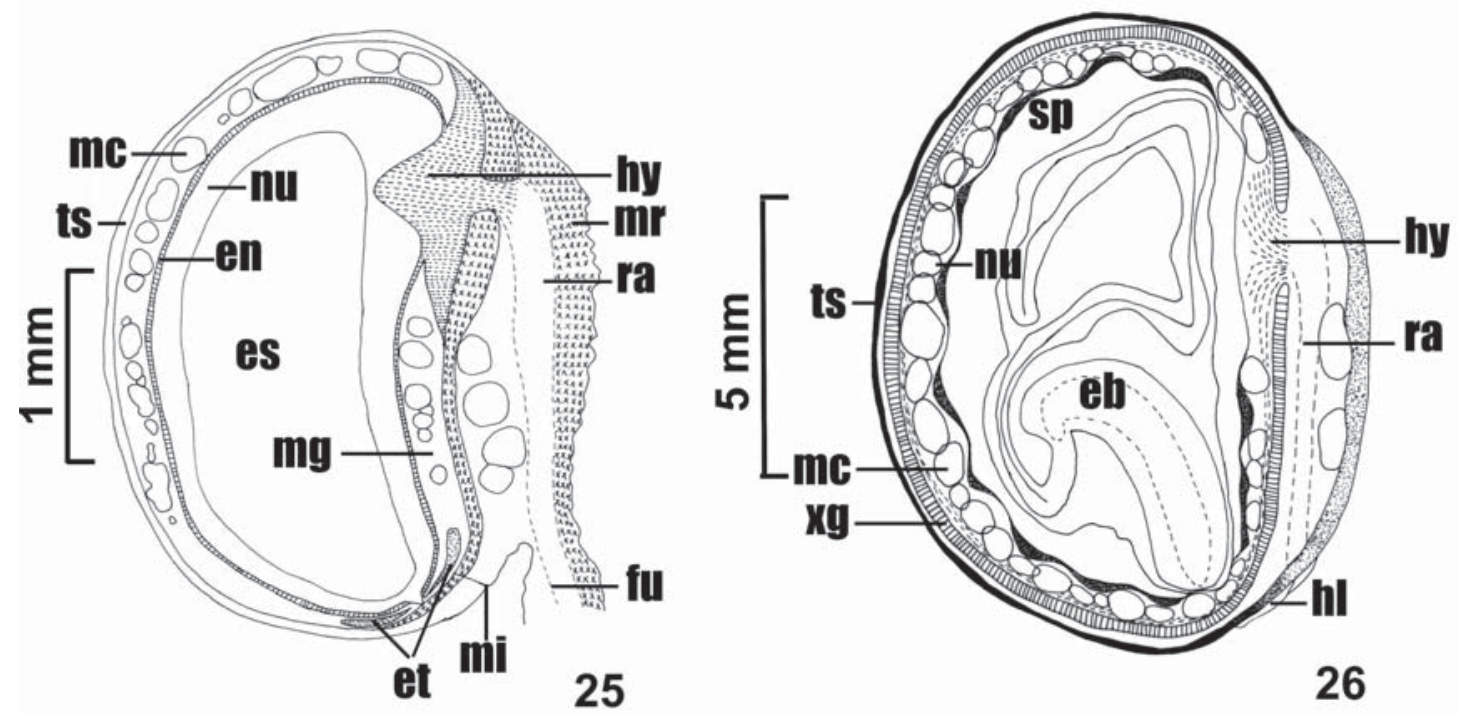

Figures 25-26. Chorisia speciosa. Diagrams, in longitudinal section, of the very young and mature seed, respectively. (eb = embryo, en = endothelium, es = embryonic sac, et $=$ epistase, $\mathrm{fu}=$ funicle, $\mathrm{hl}=$ hilum, hy $=$ hypostase, $\mathrm{mc}=$ mucilagenous cavity, $\mathrm{mg}=$ mesotegmen, $\mathrm{mi}=$ micropylar channel, $\mathrm{mr}=$ meristem, $\mathrm{nu}=$ nucellus, $\mathrm{ra}=\mathrm{raphe}, \mathrm{sp}=\mathrm{endosperm}, \mathrm{ts}=\mathrm{testa}, \mathrm{xg}=$ exotegmen).

After fertilization, the seed (figures 18-20) undergoes a curvature, due to a greater development of the anti-raphe, becoming campilotropous (figures 25-28). In the chalaza, the number of cells with phenolic contents increases, extending through the mesotegmen and nucellus (figure 17). In continuity with them, an endothelium constituted by cubic cells, also with phenolic contents, is differentiated in the most internal layer of the tegmen (figures 25, 29). The nucellar cap cells and tegmen cells, which surround the endostoma, also present phenolic contents. The tegmen cells constitute an epistase that continues to the endothelium (figures 25, 28). In this phase, stomata in the exostesta and mucilaginous secretory cavities in the mesotegmen can be observed. Periclinal divisions, constituting a meristem, can be observed in the chalazal and rapheal regions (figures $25,27,28$ ).

The occurrence of stomata in the exotesta of Bombax and Ceiba is described by Corner (1976) and in the outer epidermis of the outer integument of Ceiba insignis (Kunth) Gibbs \& Semir (= Chorisia speciosa A. St.-Hil.) by Galati \& Rosenfeldt (1997).

Kapil \& Tiwari (1978) defined integumentary tapetum or endothelium as being the inner epidermis of the inner integument of bitegmic ovules and the only integument in unitegmic ovules. In many plants, it becomes differentiated as a specialized layer of radially stretched cells with dense cytoplasm and prominent, often polyploid, nuclei. The presence of the endothelium has been recorded in 65 families of dicotyledons, but Bombacaceae has not been included among them. In Chorisia speciosa, the endothelium is not present in the ovule, differentiating itself in the young seed. However, this layer does not present radially stretched cells in this species.

According to Kapil \& Tiwari (1978) the endothelium has several functions in different developmental stages of the seeds. In the initial stages, the endothelium commonly exhibits meristematic cell ultrastructure. Once they divide profusely during the first ontogenetic stages of the megagametophyte and of the endosperm, the endothelial cells coordinate the development between the embryonic sac, the young endosperm and the integument. In other stages, the endothelium channels nutritious substances to the embryonic sac and to the endosperm. In several species, the endothelium starts to present a protective function of the embryo, during seed development. Probably, this would be the function of this layer in Chorisia speciosa, but only ultrastructural studies can elucidate its function.

The term hypostase has been proposed by Van Tieghen and Johansen apud Tilton (1980) to designate any modification occurring in the chalaza. Tilton (1980), after extensive discussion, suggests the following definition for hypostase: "a group of modified cells with usually lignified walls, generally within the chalazal region of the ovule, but which may surround a portion 
of the megagametophyte and extend partially into the micropylar half of the ovule".

Von Teichman \& Van Wyk (1991), on the other hand, distinguished a hypostase sensu stricto from one sensu lato. The former comprises a group of nucellus cells with slightly thickened walls in the chalazal extremity of the embryonic sac. This group of cells does not undergo any secondary extension, nor does it take part in the formation of the seed coat. The hypostase sensu lato consists of nucellar cells in the chalazal region that initially form a disk-like plate, show tanniniferous cell contents and undergo extensive secondary proliferation together with the chalaza and take part in seed coat development.

Tanniniferous cell contents present in the chalazal region, in the endotegmen and in the micropilar region of the ovule and seed of Chorisia speciosa are in agreement with the hypostase definition proposed by Tilton (1980), not with the Von Teichman \& Van Wyk (1991) definition, in which the use of the term is restricted to the changes which occur in nucellar cells.

According to Bhojwani \& Bhatnagar (1974), cells which show cutinized walls in the nucellar epidermis, in opposition to the hypostase, receive the denomination epistase. In the seed of Chorisia speciosa, the term epistase has been used to designate a group of cells with phenolic contents present in the nucellar cap and the tegmen region, which surround the endostome. With seed development, tanniniferous cell contents are restricted to the hypostase and the endostomal epistase (figure 30), collapsing in the endothelium and the nucellar cap.

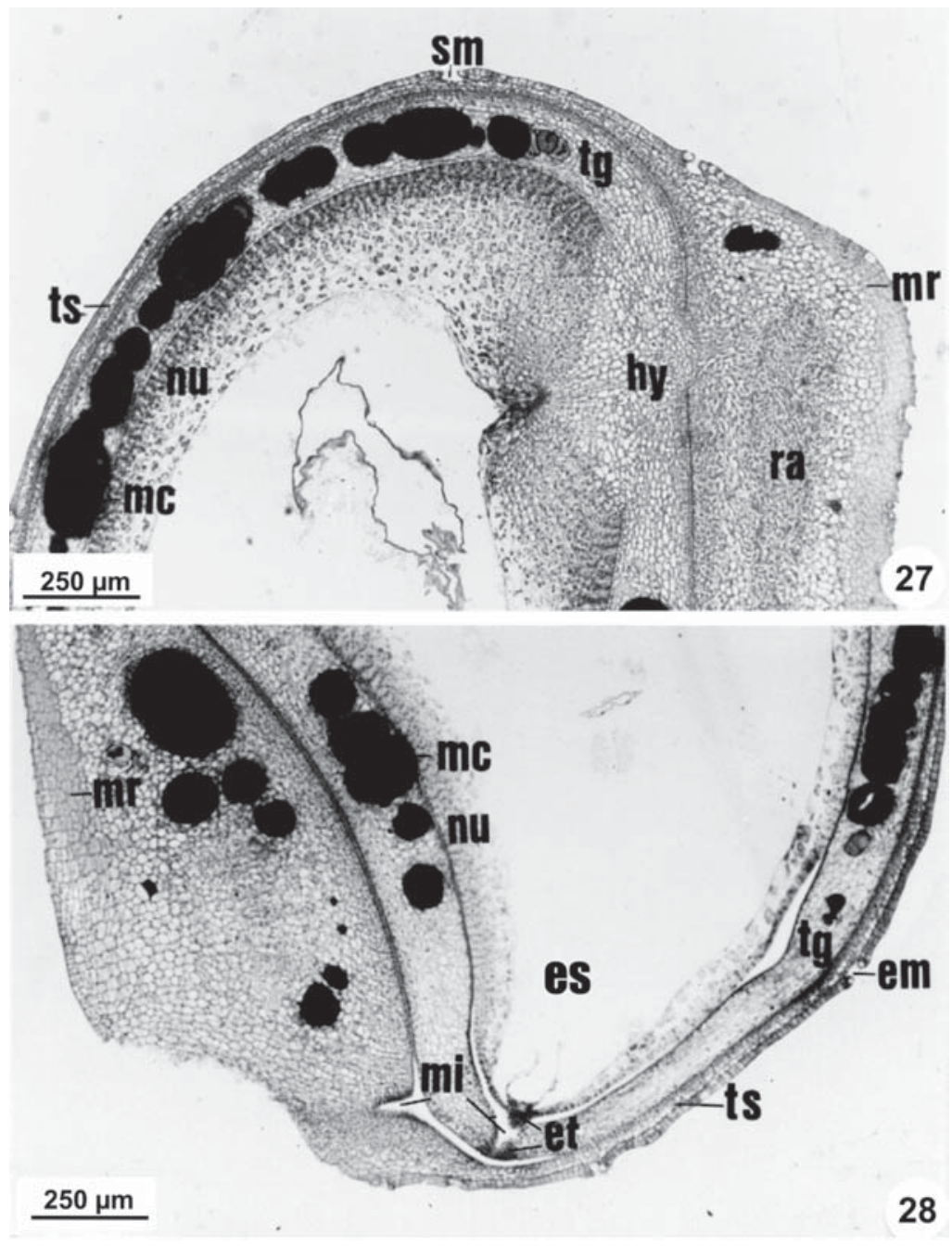

Figures 27-28. Chorisia speciosa. Very young seed, in longitudinal section, evidencing the chalazal and micropylar regions, respectively. (es = embryonic sac, et $=$ epistase, hy $=$ hypostase, $\mathrm{mc}=$ mucilagenous cavity, $\mathrm{mi}=$ micropylar channel, $\mathrm{mr}=$ meristem, $\mathrm{nu}=$ nucellus, $\mathrm{ra}=$ raphe, $\mathrm{sm}=$ stomata, $\operatorname{tg}=$ tegmen, $\mathrm{ts}=$ testa $)$. 

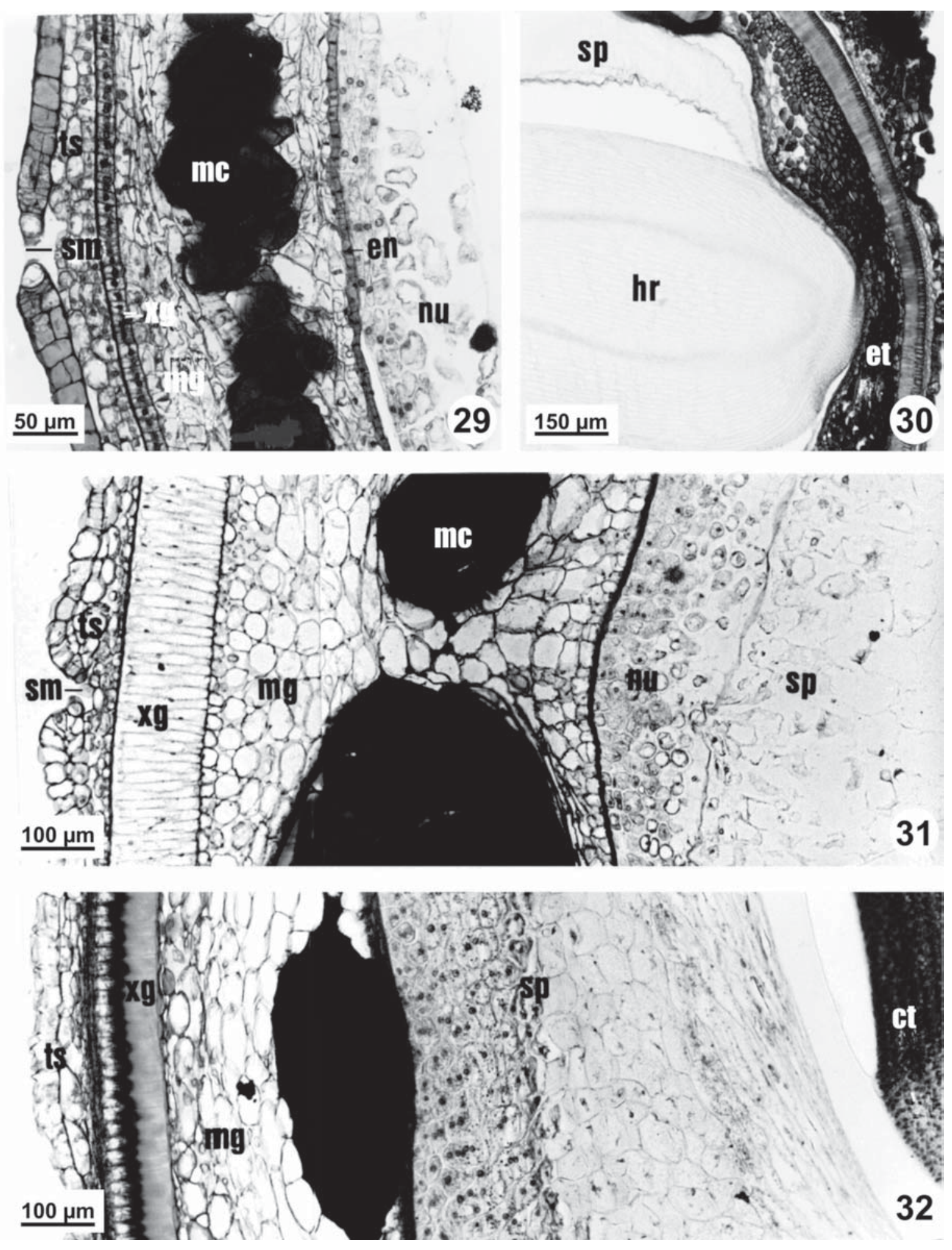

Figure 29-32. Chorisia speciosa. 29-31. Detail of the integument, in transversal section, of a very young, immature and mature seed, respectively. 32. Detail of the micropyle of a mature seed, in longitudinal section. $(\mathrm{ct}=$ cotyledons, en $=$ endothelium, et $=$ epistase, $\mathrm{hr}=$ hipocotyl-radicle axis, $\mathrm{mc}=$ mucilagenous cavity, $\mathrm{mg}=$ mesotegmen, $\mathrm{nu}=$ nucellus, $\mathrm{sm}=$ stomata, $\mathrm{sp}=$ endosperm, ts $=$ testa, $\mathrm{xg}=$ exotegmen). 
Tilton (1980) mentions that the function of the hypostase is not known with certainty, but because of its position around the megagametophyte, it is generally thought to be related to the translocation of nutrients, into the megagametophyte and embryo. In Chorisia speciosa, due to the position of the hypostase sensu Tilton (1980), this is probably its function.

Mature seeds are dark (almost black) (figure 13), obovoid in shape, slightly flattened in the rapheal region and present a verrucose integument. The hilum is rounded, and shows a clearer coloration. The micropyle is obscure and the raphe is prominent and darker than the rest of the integument (figures 21-22).

The bitegmic mature seed continues campilotropous and presents a small quantity of endosperm. The uniseriate testa is entirely formed by the exotesta, the other layers having collapsed. The exotegmen is completely constituted by macrosclereids, which begin differentiation in the young seed, becoming elongated and lignified later. The mucilaginous secretory cavities in the mesotegmen are more developed in this phase and the endotegmen, constituted by the endothelium, becomes crushed (figures 26, 29-32). The white embryo occupies the entire seminal cavity and presents a slightly curved cylindrical hipocotyl-radicle axis and conduplicate cotyledons (figures 24,26). The endosperm and the embryo are rich in lipid material, but show a small quantity of starch.

Anatropous and bitegmic ovules, micropyle constituted by the exostome, exotegmen constituted by a palisade of lignified Malpighi cells are features described in Adansonia digitata L., Coelostegia griffithii Benth. and Pachira insignis Savigny by Corner (1976) that also occur in Chorisia speciosa. This author also described the occurrence of endosperm rich in lipids and folded cotyledons in Bombacaceae.

Corner (1976) affirms that the basic distinctive character of the seed coat is the position and structure of the main mechanical layer, composed of one or more layers with thick cell walls, but not necessarily lignified. According to his classification, the seed of Chorisia speciosa is exotegmic.

According to the Martin (1946) embryo classification, adapted by C.M. Beltrati (unpublished data), the embryo of Chorisia speciosa is plicate.

\section{References}

BARROSO, G.M., MORIM, M.P., PEIXOTO, A.L. \& ICHASO, C.L.F. 1999. Frutos e sementes: morfologia aplicada à sistemática de dicotiledôneas. Universidade Federal de Viçosa, Viçosa.
BHOJWANI, S.S. \& BHATNAGAR, S.P. 1974. The embryology of angiosperms. Vikas Publishing House, Delhi.

CORNER, E.J.H. 1976. The seeds of dicotyledons. E.J.H. Corner, ed. Cambridge University Press, Cambridge.

CRONQUIST, A. 1981. An integrated system of classification of flowering plants. Columbia University Press, New York.

DIAS, L.A.S., KAGEYAMA, P.Y. \& ISSIKI, K. 1992. Qualidade de luz e germinacão de sementes de espécies arbóreas e tropicais. Acta Amazonica 1:79-84.

DONATO, A.M. 1991. Anatomia floral de Chorisia speciosa A. St.-Hil. (Bombacaceae). Bradea 5:455-477.

GALATI, B.G. \& ROSENFELDT, S. 1997. Ovule ontogenesis in Ceiba insignis (Kunth) Gibbs \& Semir (ex Chorisia speciosa A. St.-Hil.) (Bombacaceae). Phytomorphology 3:247-253.

GERRITS, P.O. 1991. The application of glycol methacrylate in histotechnology, some fundamental principles. Department of Anatomy and Embryology State University, Gröningen.

JENSEN, W.A. 1962. Botanical histochemistry, principles and practice. W.H. Freeman, San Francisco.

JOHANSEN, D.A. 1940. Plant microtechnique. McGraw-Hill Book Co., New York.

JUDD, W.S., CAMPBELL, C.S., KELOGG, E.A. \& STEVEN, P.F. 1999. Plant systematics, a phylogenetic approach. Sinauer Associates, Sunderland.

KAPIL, N.R. \& TIWARI, S.C. 1978. The integumentary tapetum. The Botanical Review 44:457-490.

MARTIN, A.C. 1946. The comparative internal morphology of seeds. The American Midland Naturalist 36:513-660.

MOURÃO, K.S.M. \& BELTRATI, C.M. 1995. Morfologia dos frutos, sementes e plântulas de Platonia insignis Mart. (Clusiaceae). I. Aspectos anatômicos dos frutos e semente em desenvolvimento. Acta Amazonica 25:11-32.

O'BRIEN, T.P., FEDER, N. \& MCCULLY, M.E. 1964. Polychromatic staining of plant cell walls by toluidine blue O. Protoplasma 59:368-373.

PIO CORRÊA, M. 1978. Dicionário das plantas úteis do Brasil e das exóticas cultivadas. Ministério da Agricultura, Rio de Janeiro.

RADFORD, A.E., DICKSON, W.C., MASSEY, J.R. \& BELL, C.R. 1974. Vascular plant systematic. Harper \& Row Publishers, New York.

RAMALHO, R.S. 1972. Paineira (Chorisia speciosa St.-Hil.). UFV, Viçosa.

ROTH, I. 1977. Fruits of angiosperms. In Encyclopedia of plant anatomy (K. Linsbauer, ed.). Gebruder Borntraeger, Berlin. v.10, n.1, p.1-38.

SANTOS, E. 1967. Bombacáceas. In Flora Ilustrada Catarinense (R. Reitz, ed.). Herbário Barbosa Rodrigues. Itajaí.

SCHIMID, R. 1986. On cornerian and other terminology of angiosperms and gymnosperms seed coats: historical perspective and terminological recommendations. Taxon 35:476-491. 
SPJUT, R.W. 1994. A systematic treatment of fruit types. Memoirs of the New York Botanical Garden 70:1-82.

TILTON, V.R. 1980. Hypotase development in Ornithogalum caudatum (Liliaceae) and notes on the other types of modifications in the chalaza of Angiosperm ovules. Canadian Journal of Botany 58:2059-2066.
VON TEICHMAN, I. \& VAN WIK, A.E. 1991. Trends in the evolution of dicotyledonous seeds based on character association, with special reference to pachychalazy and recalcitrance. Botanical Journal of Linnean Society of London 105:211-237. 